MINIREVIEWS

\title{
Structure and function of oncogene-transfected immortal cells
}

\author{
V. M. Kavsan ${ }^{1}$, T. A. Kulagova ${ }^{2}$, T. A. Kuznetsova ${ }^{3}$, G. N. Semenkova ${ }^{3}$,
}

A. A. Stepanenko', Y. S. Vassetzky ${ }^{4}$

${ }^{1}$ State Key Laboratory of Molecular and Cellular Biology,
Institute of Molecular Biology and Genetics, NAS of Ukraine
150, Akademika Zabolotnoho Str., Kyiv, Ukraine, 03680
${ }^{2}$ Belarusian State University
4, Nezavisimosti avenue, Minsk, Republic of Belarus, 220030
${ }^{3}$ N. I. Pirogov Russian National Research Medical University
1, Ostrovitianov Str., Moscow, Russian Federation, 117997
${ }^{4}$ CNRS UMR8126, Paris-Sud University, Gustave Roussy Institute
114, rue Edouard Vaillant, 94805 Villejuif Cedex-France

Previously we have characterized a new oncogene CHI3L1, overexpressed in the glioblastoma and the malignant 293_CHI3L1 cells, stably producing the CHI3L1 angiogenic oncoprotein. The 293_CHI3L1 cells proliferated faster and acquired a higher ability for anchorage-independent growth. Here, we report the atomic force microscopy data and functional characteristics of these cells. The constitutive CHI3L1 expression leads to the increased resistance to the damages by oxidative substances and promotes the chromosome instability in the 293 cells. According to the data of the last clinical investigations, anti-cancer therapy should be targeted not at the individual genes, but at the pathological effects they caused. We propose a complex treatment of gliomas including multi-target inhibitors, which can be delivered to the brain tumor by a specific nanoparticle vector.

Keywords: oncogene CHI3L1, atomic force microscopy, reactive oxygen species (ROS), 293 cells (HEK293), combinatorial chemotherapy, chromosome instability (CIN).

Previously we have characterized a new oncogene CHI3L1, overexpressed in the glioblastoma [1], and the malignant 293_CHI3L1 cells, stably producing the CHI3L1 oncoprotein [2]. The 293_CHI3L1 cells proliferated faster and acquired a higher ability to anchorage-independent growth than the 293 cells, which were stably transfected with an «empty» vector without a CHI3L1 cDNA insert. Here we report the atomic force microscopy data and functional characteristics of these cells.

Atomic force microscopy showed that the 293 cells, generated by transformation of human embryonic kidney cells with sheared adenovirus 5 DNA [3] and transfected by an «empty» vector (293 pcDNA3.1 cells),

\footnotetext{
(C) Institute of Molecular Biology and Genetics, NAS of Ukraine, 2014
}

had a round body with 3-5 long outgrowths, which joined several neighbor cells with free space between them. The space occupied by the net of such cells reminded the organization of neuronal nets that is one more confirmation of the neuronal origin of the 293 cells [4]. CHI3L1 production induced the morphological changes: increased space of cell body on the substrate, bigger cell height and body volume, different distribution on the substrate, loss of long outgrowths, spindle shape (they are stretched and sharp-edged with short wide outgrowths for the contact with neighbor cells) accompanied by reorganization of actin cytoskeleton, a major mediator of cell migration and invasion (Fig. 1).

The expression of the CHI3L1 gene leads to an increased resistance of the 293_CHI3L1 cells to the oxidants $\left(\mathrm{H}_{2} \mathrm{O}_{2}\right.$, sodium hypochloride and peroxynitrite do- 

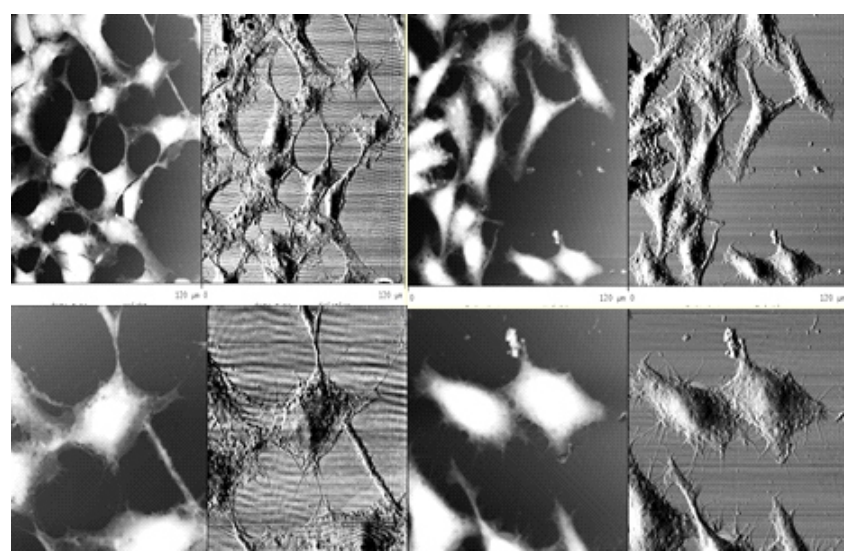

293 pcDNA3.1 cells

293_CHI3L1 cells

Fig. 1. AFM images of 293 pcDNA3.1 and 293_CHI3L1 cells

nor SIN-1). The rate constant of $\mathrm{H}_{2} \mathrm{O}_{2}$ scavenging in the 293 CHI3L1 cells is 2.7-fold higher than that in the immortalized but not yet malignant 293 cells. It was revealed that the 293_CHI3L1 cells generated reactive oxygen species (ROS) under menadione action more intensively than the original cells. The activities of enzymes participating in the menadione-induced generation of ROS are regulated by the JNK-mitogen activated protein kinase and phosphatidylinositol-3-kinase in the 293_CHI3L1 cells. The elevated levels of reduced glutathione, a major cellular antioxidant, may at least partially explain an increased resistance of the 293_CHI3L1 cells to the oxidative stress. A higher resistance of the cancer cells to $\mathrm{H}_{2} \mathrm{O}_{2}$ reduced their vulnerability to the ROS action. The addition of antioxidant drugs may even increase this effect. These results are in a good correspondence with the recently published conception of Watson [5] about the importance of the ROS and antioxidants in the tumor development.

The combinatorial chemotherapy came of age in the 1970s and its achievements and failures are well documented by now. Of course, much remains to be learned why it is active in certain situations and decidedly inactive in others; variable apoptotic threshold is a possible explanation. The unstable genome is more likely generates resistant variants, which are then selected to survive. "The Heng-Duesberg model, or any other model identifying accelerated macroevolution as the central fact of cancer, would also account for the rapid emergence of resistant variants, as would «adaptive resilience» as an ancient trait» [6]. In our experiments the 293 cells (human embryonic kidney cells known as HEK293) were used as control original cells. They are immortal and, like other immortalized cells, they could indefinitely proliferate and their proliferation ability depended on nutrients and growth factors. However, they could not grow over one another in cell culture (contact inhibition), improperly formed colonies in soft agar (anchorage-dependent growth), and did not form tumors when injected into the immune competent rodents. All these characteristics appeared with additional chromosome changes in the 293_CHI3L1 cells (Fig. 2).

A main driver of tumor evolution is the genetic heterogeneity, which is fostered by the chromosome instability (CIN). Here we evidence that constitutive expression of CHI3L1 promotes chromosome instability in 293 cells. The modal chromosome number in the 293_CHI3L1 clone 1 (69-73) and in the 293_CHI3L1 clone 2 cells (72-74) was different from that in the parental 293 cells (67-72). Interline whole chromosome heterogeneity was manifested in all three cell lines. A number of new distinct marker chromosomes were observed in the CHI3L1-expressing clones. The array comparative genome hybridization ( $\mathrm{aCGH}$ ) was used to analyze the sub-chromosomal alterations in these cell lines. The spectrum of cytoband gains and losses in the 293 CHI $3 L 1$ clone 1 and clone 2 cells is similar but differs from the parental 293 cells. The karyotypes of these cells are unique, completely different from other immortal and malignant cells in culture as well as from all tumor cells. According to Duesberg et al. [6], cancer cell is a unique unicellular eukaryotic species and, moreover, like Vincent proposed [7], cancer may be seen as a entire bunch of different (unicellular) species, because there are hardly two cancer cells with exactly the same genome.

CHI3L1 similarly to other oncogenes was like a trigger in the transformation of the immortal 293 cells into the malignant 293_CHI3L1 cells. However, the census of cancer genes includes about 500 human tumor-associated genes. Nevertheless, an overwhelming amount of diverse molecular information offers only limited understanding of general mechanisms of the cancer development. According to the new evolutionary karyotypic concept of cancer, tumor evolution is a macro-evolutionary process, where karyotype or stochastic genome-level alterations play a dominant role. The engine for karyotype evolution is the chromosome instability, which 


\section{8}

$B$

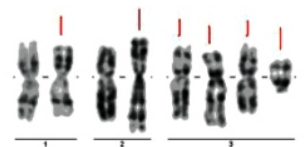

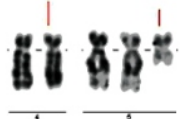

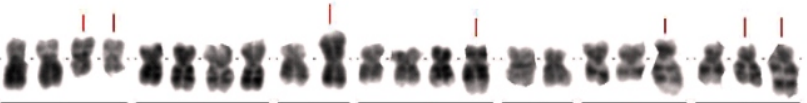

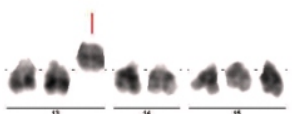

a.t.

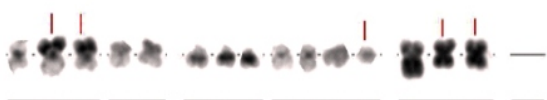

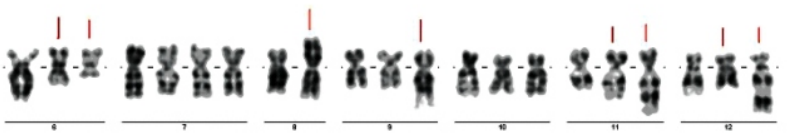
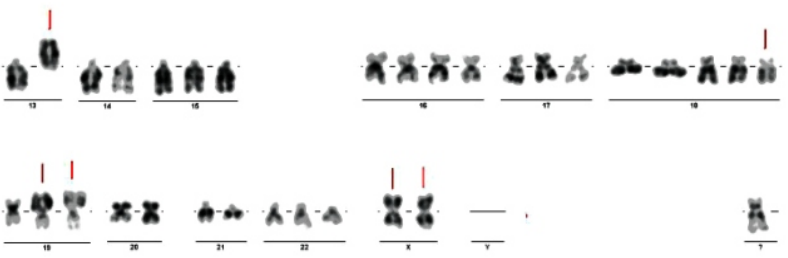

Fig. 2. Representative karyograms of the 293 cells $(A)$ and 293_CHI3L1 (clone 2) cells $(B)$. Abnormal chromosomes are marked with red lines above corresponding chromosomes

results from persistent defects in mitotic fidelity and implies both total and segmental chromosome instability (translocations, deletions, and amplifications). CIN allows quick changes in doses of multiple genes and represents early and causative event in cancer progression which significantly correlates with the acquired therapy resistance (Duesberg et al. [6], reviewed in [8]).

The single markers and targets alone do not have a significant clinical value, high heterogeneity of glial tumors requires the simultaneous analysis of many genes and the therapy aimed not at the individual genes, but at the physiological effect they caused. One of such physiological effects is angiogenesis, which plays a key role in tumor vascularization. In anticancer therapy, considerable attention is paid to the anti-angiogenic drugs. Previously, it has been shown that CHI3L1 has a strong angiogenic effect. We found that knockdown of CHI3L1 in the 293_CHI3L1 cells by specific siRNAs decreased the production of CHI3L1 to $10 \%$. Nevertheless, the success of angiogenic drugs in clinic is a temporary one: drug resistance, tumor reemergence, and rapid appearance of new vessels develop at the end of therapy. Angiogenic (oncogenic) redundancy is a significant obstacle to the success of targeting therapy. It is supposed that simultaneous treatment with the anti-CHI3L1 and anti-VEGF drugs should give better result. Bradykinin antagonists and azolidinone derivatives were shown to be quite promising as new potential anti-cancer compounds for the complex therapy at least in the cell cultures and the in vivo rat model experiments. The search for new targets was performed by cluster analysis of the data on gene expression in the glioblastoma and normal brain samples by self-organising Kohonen's maps.

For multiple-target drugs delivery to the gliomas we are planning to use a specific vector, Polycefin [9] comprising necessary features: penetration across the bloodbrain barrier and tumor-normal brain barrier, highly-selective accumulation of the therapeutic agent in tumors, lack of toxicity, non-immunogenicity, biodegradation, stability in the bloodstream. Additionally the inhibitors of multiple molecular targets should be easily attached to one vector molecule.

Funding. This work was supported by the State Fund of Fundamental Research of Ukraine grant N F46/3662013

Структура і функція імморталізованих клітин, трансформованих онкогеном

В. М. Кавсан, Т. А. Кулагова, Т. А. Кузнецова, Г. М. Семенкова, А. А. Степаненко, С. С. Васецький

Резюме

Раніше нами охарактеризовано новий онкоген CHI3L1, який суперекспресується в гліобластомі та злоякісних клітинах 293_CHI3L1, що стабільно продукують ангіогенний онкобілок CHI3L $\overline{1}$. Клітини 293_CHI3L1 проліферують швидше і набувають більшої здатності до незалежного від основи росту. Наведено дані атомносилової мікроскопї та функціональні характеристики зазначених клітин. Конститутивна експресія CHI3L1 підвищує стійкість до пошкоджень речовинами-окиснювачами і сприяє нестабільності хромосом у клітинах 293. За даними останніх клінічних випробувань, протиракова терапія повинна бути націлена не на індивідуальні гени, а на спричинені ними патологічні ефекти. Ми 
пропонуємо комплексне лікування гліом із залученням багатомішенних інгібіторів, які можна доствляти до пухлин головного мозку специфічним вектором на основі наночасток.

Ключові слова: онкоген CHI3L1, атомно-силова мікроскопія, активні форми кисню (АФК), клітини 293 (HЕК-293), комбінаторна хіміотерапія, хромосомна нестабільність (CIN).

Структура и функция иммортализованных клеток, трансформированных онкогеном

В. М. Кавсан, Т. А. Кулагова, Т. А. Кузнецова, Г. Н. Семенкова, А. А. Степаненко, Е. С. Васецкий

Резюме

Ранее нами охарактеризован новый онкоген CHI3L1, суперэкспрессируюшийся в глиобластоме и злокачественных клетках 293_CHI3L1, стабильно продуцирующих ангиогенный онкобелок CHIЗLL1. Клетки 293_СНIЗL1 пролиферируют быстрее и приобретают больиую способность к независимому от подложки росту. Приведены данные атомно-силовой микроскопии и функииональные характеристики указанных клеток. Конститутивная экспрессия CHI3L1 повышает устойчивость к повреждениям вещеествами-окислителями и способствует нестабильности хромосом в клетках 293. По данным последних клинических испьтаний, противораковая терапия должна быть нацелена не на индивидуальные гены, а на вызываемые ими патологические эффекты. Мы предлагаем комплексное лечение глиом с привлечением мультимишенных ингибиторов, которые можно доставлять к опухолям головного мозга специфическим вектором на основе наночастиц.

Ключевые слова: онкоген CHI3L1, атомно-силовая микроскопия, активные формы кислорода (АФК), клетки 293 (НЕК-293), комбинаторная химиотерапия, хромосомная нестабильность $(C I N)$.

\section{REFERENCES}

1. Garifulin OM, Shostak KO, Dmitrenko VV, Rozumenko VD, Khomenko OV, Zozulya YuP, Zehetner G, Kavsan VM. The genes $S O X-2$ and $H C g p-39$ are overexpressed in astrocytic gliomas. Biopolym Cell. 2002; 18(4):324-9.

2. Kavsan VM, Baklaushev VP, Balynska OV, Iershov AV, Areshkov PO, Yusubalieva GM, Grinenko NP, Victorov IV, Rymar VI, Sanson M, Chekhonin VP. Gene encoding chitinase 3-like 1 protein (CHI3L1) is a putative oncogene. Int J Biomed Sci. 2011; 7(3):230-7.

3. Graham FL, Smiley J, Russell WC, Nairn R. Characteristics of a human cell line transformed by DNA from human adenovirus type 5. J Gen Virol. 1977; 36(1):59-74.

4. Shaw G, Morse S, Ararat M, Graham FL. Preferential transformation of human neuronal cells by human adenoviruses and the origin of HEK 293 cells. FASEB J. 2002; 16(8):869-71.

5. Watson J. Oxidants, antioxidants and the current incurability of metastatic cancers. Open Biol. 2013; 3(1):120144.

6. Duesberg P, Mandrioli D, McCormack A, Nicholson JM. Is carcinogenesis a form of speciation? Cell Cycle. 2011; 10 (13): 2100-14.

7. Vincent MD. Cancer: beyond speciation. Adv Cancer Res. 2011; 112:283-350.

8. Stepanenko AA, Kavsan VM. Evolutionary karyotypic theory of cancer versus conventional cancer gene mutation theory. Biopolym Cell. 2012; 28(4):267-80.

9. Ljubimova JY, Fujita M, Khazenzon NM, Lee BS, WachsmannHogiu S, Farkas DL, Black KL, Hollerb E. Nanoconjugate based on polymalic acid for tumor targeting. Chem Biol Interact. 2008; 171(2):195-203 